\title{
NUTRITIONAL COMPOSITIONS OF SIX EDIBLE INSECTS IN JAVA
}

\author{
Kuntadi*, Yelin Adalina and Kun E. Maharani \\ Forest Research and Development Center, \\ Jl. Gunung Batu 5, Bogor 16110, West Java, Indonesia
}

Received: 27 July 2017, Revised: 24 April 2018, Accepted: 26 April 2018

\begin{abstract}
NUTRITIONAL COMPOSITIONS OF SIX EDIBLE INSECTS IN JAVA. Nutritional deficiency is still a problem faced by many families in Indonesia. One of the important issues is the level of protein consumption that is still below the minimum required standard. Edible insects could be one alternative of protein sources since their availability in the nature is quite abundant. This paper analyses six edible species of both cultivated and wild insects for its proximate compositions to measure their nutritional value. The cultivated insects consist of cricket (Gryllus sp.), giant mealworm (Zophobas morio F.), yellow mealworm (Tenebrio molitor L.), and silkworm (Bombyx mori L.), and the wild insects consist of javanese grasshopper (Valanga nigricornis Burm.) and paddy locust (Nomadacris succincta L.). Results shows that the nutritional composition of insects varies widely. Each $100 \mathrm{~g}$ of dry weight contains of $32.59-76.69 \%$ of protein, $6.9-29.47 \%$ of fat, $0.92-30.76 \%$ of carbohydrate, $2.80-5.79 \%$ of ash, $407.34-517.50 \mathrm{kcal}$ of energy, and minerals about $24.82-31.22 \mathrm{mg}$ of calcium (Ca) and 3.15-4.1 $\mathrm{mg}$ of iron $(\mathrm{Fe})$. Some species such as grasshoppers, silkworm pupae and crickets have high protein content which potentially can be utilized as an alternate protein sources to fight against malnutrition and to increase nutritious food consumption. Efforts should be made to encourage the consumption of edible insects as an alternative source of protein. It is especially important to those who live in and around the forest, since the forest area is an excellent habitat for various species of insects.
\end{abstract}

Keywords: Insect, proximate analysis, nutritional value, food

KANDUNGAN NUTRISI ENAM JENIS SERANGGA LAYAK KONSUMSI DI JAWA. Kekurangan pangan dan nutrisi masih menjadi persoalan yang dibadapi banyak keluarga di Indonesia. Salah satu persoalan penting dalam permasalaban tersebut yaitu tingkat konsumsi protein yang masib di bawah standar kebutuhan minimum. Serangga dapat menjadi alternatif terbaik, penyedia protein hewani mengingat ketersediaannya di alam cukup melimpah. Tulisan ini mempelajari komposisi proksimat, potensi nutrisi, dan nilai gizi enam jenis serangga layak. konsumsi, baik yang berasal dari kegiatan budi daya maupun yang berasal dari alam. Serangga hasil budi daya terdiri dari jangkrike (Gryllus sp.), ulat jerman (Zophobas morio F.), ulat hongkong (Tenebrio molitor L.), dan pupa ulat sutera (Bombyx mori L.), adapun serangga hasil tangkapan dari alam terdiri dari belalang kayu (Valanga nigricornis Burm.) dan belalang jerami Nomadacris succincta L.). Hasil penelitian menunjukkan kandungan nutrisi masing-masing jenis serangga sangat bervariasi. Setiap 100g berat kering specimen serangga mengandung protein 32,59-76,69\%, lemak 6,9-29,47\%, karbobidrat 0,92-30,76\%, abu 2,80-5,79\%, energi 407,34-517,50 keal, serta mineral Ca dan Fe sekitar 24,82-31,22 $\mathrm{mg}$ dan 3,15-4,1 mg. Beberapa jenis serangga seperti belalang, pupa ulat sutera, dan jangkrik memiliki kandungan protein yang tinggi sehingga sangat potensial untuk dimanfaatkan sebagai alternatif sumber protein dalam upaya memerangi masalah malnutrisi dan meningkatkan konsumsi makanan bergizi. Berbagai upaya perlu dilakukan untuk mendorong pemanfaatan serangga sebagai alternatif sumber protein hewani. Pemasyarakatan konsumsi serangga perlu dilakukan bagi masyarakat pedesaan dan yang tinggal di sekitar butan mengingat kawasan hutan merupakan habitat beragam jenis serangga.

Kata Kunci: Serangga, analisis proksimat, nilai nutrisi, makanan

*Corresponding author: kuntadi@ forda-mof.org 


\section{INTRODUCTION}

Nutritional deficiency is still a problem faced by many families in Indonesia. Basic Health Research in 2013 revealed that malnutrition rates in infants reached $19.6 \%$, consisting of $5.7 \%$ severe malnutrition and $13.9 \%$ moderate malnutrition. In 2010 it was recorded that about eight million children under five years old were stunted (body height is lower than normal child) due to less nutritional prevalence (Asthami, Estiasih, \& Maligan, 2016). Hariyadi (2015) stated that the impact of malnutrition is not only related to inadequate consumption of calories but also the lack of various nutrient' intake which affect widely to the quality of life.

Protein is a source of nutrients that has an important role in the metabolism and biological functions in the body. Indonesia is one of the countries with low consumption of animal source protein, even at ASEAN level. Based on Protein Sufficient Value (PSV) derived from the population composition of 2010, it was obtained that the national PSV was about $57 \mathrm{~g}$ per person per day with $25 \%$ of them is recommended coming from animal source protein (Hardinsyah, Riyadi, \& Napitupulu, 2013). The daily protein intake value is much lower than in developed countries that reach 96 g per person per day with much greater proportion of animal source protein with at least $65 \%$ of it is coming from meat (Mlcek, Rop, Borkovcova, \& Bednarova, 2014). This situation occurred because of the inadequate supply of livestock in the country coupled with the low purchasing power of the local society.

Since there are risks that may occur in the future, various efforts should be continuously committed to improve the quality of dietary intake, including the need for animal protein from various sources which have not been utilized. Insects could be one of the best alternative animal protein source since their availability in the nature is quite abundant and many of them can be cultivated at a cheaper cost, both economically and environmentally (Payne, Scarborough, Rayner, \& Nonaka, 2016).

Insect is a class of organisms that are very dominant among living creatures that exist on earth. Their number both species and population account for the greatest amount of biodiversity in the forest and many of them have long been harvested for food (Durst \& Shono, 2010). It is estimated that more than 2000 species of insects are edible (Kourrimská \& Adámková, 2016). These insects are dominated by the order of Coleoptera (beetles) 31\%, Lepidoptera (butterflies) 18\%, Hymenoptera (bees/wasps) 14\%, Orthoptera (crickets/grasshoppers) 13\%, and other orders about 23\% (van Huis et al., 2013). As tropical country and owned the third largest forest areas in the world, Indonesia is a home of insects biodiversity and many of them are edible which could be utilized to fulfil the need of protein inadequacy.

Entomophagy (eating insects) has became a common practice in some African, Asian and Latin American countries (Pal \& Roy, 2014). Currently, entomophagy is practiced in 113 countries in the world (Kouřimská \& Adámková, 2016). Thailand is the most successful country in Asia that provide insects as food commodity, even a popular menu in their daily meal (Halloran, Vantomme, Hanboonsong, \& Ekesi, 2015). There are at least 164 arthropod species sold and traded in the traditional markets to super market in Bangkok (Pal \& Roy, 2014).

The habit of eating insects has long been done by some people in some regions in Indonesia (Bodenheimer, 1951). In some areas, entomophagy is still practiced nowadays such as in teak forests in Central and East Java Provinces during caterpillar (Hyblaea puera Cramer) attack, local communities are looking for the pupae for food (Lukiwati, 2010). In Molucca Islands and Papua, some people commonly consume the larvae of sago beetle (Rhynchophorus bilineatus Montrouzier) (Ramandey \& van Mastrigt, 2010). While in some areas of Gunung Kidul Regency, Yogyakarta Special Province, grasshoppers became daily menu of dishes and sold everyday.

Insects are well known for being rich in nutrients, containing proteins, carbohydrates, fats, minerals and vitamins (Durst \& Shono, 2010; Mlcek et al., 2014). Some species are 
known to have nutritional value comparable to meat and fish, some of which contain higher levels of protein, fat and energy values (Alamu, Amao, Nwokedi, Oke, \& Lawa, 2013). Each type of insect contains protein in different percentages, which generally is of high quality and easily digested (Ramos-Elorduy et al., 1997). This paper studies the nutritional value of insects commonly consumed by some communities and some species that have been cultivated for other purposes (primarily as animal feed) but considerably appropriate for human consumption.

\section{MATERIAL AND METHOD}

\section{A. Study Site}

This study was conducted in October and November 2016. Six specimens of insect were collected. Four species were cultivated insects, namely crickets (Gryllus sp.), yellow mealworm (Tenebrio molitor L.), giant mealworm (Zophobas morio F.), and silkworm (Bombyx mori L.). Two other species were captured from the nature i.e. javanese grasshopper (Valanga nigricornis Burm.) and paddy locust (Nomadacris succincta L.). These species were considered as edible insects according to several authors (Feng et al., 2018; Paul et al., 2017; Payne et al., 2016; Rumpold \& Schlüter, 2013).

Samples of cultivated insects were collected from the area around Bogor, West Java. Cricket, yellow mealworm, and giant mealworm were purchased from pet shop, while silkworm pupae was obtained from silkworm farm. Samples of wild insects were obtained from Wonosari, Gunung Kidul Regency, where wild grasshoppers are traded and consumed daily.

\section{B. Methods}

All samples were oven-dried at $60-70^{\circ} \mathrm{C}$ for 12-24 hours (Makore, Garamumhango, Chirikure, \& Chikambi, 2015; Tiroesele, Seletlo, \& Moreki, 2013). Dry specimens were grounded separately and each specimen weighed $100 \mathrm{~g}$ for proximate analysis purposes. Proximate analysis were performed for the insect's body contents of protein, fats, carbohydrates, ash and energy.
In addition, minerals were also analyzed for their content of iron (Fe) and calcium (Ca). The analysis of proximate and mineral compositions was conducted at the laboratory of Indonesian Center for Agricultural Post-Harvest Research and Development, The Agricultural Research and Development Agency, The Ministry of Agriculture.

The analytical method followed the procedure established by the Association of Offical Analytical Chemist (AOAC, 2005). Crude protein was determined using Kjeldahl method, fat analysis was performed using soxhlet method, ash was determined using gravimetry method, and the minerals were analyzed using AAS (atomic absorption spectrophotometer) method. The analysis of carbohydrate value was performed through calculation of the difference between 100 and the sum of the percentages of water, protein, fat and ash. The energy was calculated by multiplying the mean values of fat, protein, and carbohydrate contents by their respective calorific value based on conversion factor from Atwater, that is $9 \mathrm{Kcal} / \mathrm{g}$ for fat, $4 \mathrm{Kkal} / \mathrm{g}$ for protein, $4 \mathrm{Kcal} / \mathrm{g}$ for carbohydrate.

\section{Analysis}

Data were tabulated and analyzed descriptively by comparing the nutritional value of insects between species obtained in the study with similar species obtained from other research results, both domestically and abroad, as well as with other food stuffs.

\section{RESULT AND DISCUSSION}

Result showed that nutrient content of insect varied widely between species. Proximate analysis showed that the nutritional value of insects varies among species. Table 1 shows the value of insect proximate compositions (protein, fat, carbohydrate, ash, and total energy) in $100 \mathrm{~g}$ dry weight.

The results of this study reconfirm the results of previous research (Ghosh, Lee, Jung, \& Meyer-Rochow, 2017; Payne et al., 2016), suggesting that the nutritive value of insect 
Table 1. Nutritional contents of some edible insects in $100 \mathrm{~g}$ dry weight

\begin{tabular}{lcccccc}
\hline \multicolumn{1}{c}{ Specimen } & Stadia & $\begin{array}{c}\text { Protein } \\
(\%)\end{array}$ & $\begin{array}{c}\text { Lipid } \\
(\%)\end{array}$ & $\begin{array}{c}\text { Carbohydrate } \\
(\%)\end{array}$ & $\begin{array}{c}\text { Ash } \\
(\%)\end{array}$ & $\begin{array}{c}\text { Energy } \\
(\text { Kcal })\end{array}$ \\
\hline $\begin{array}{l}\text { Javanese grasshopper } \\
\text { (Valanga nigricornis Burm.) }\end{array}$ & Imago & 76.69 & 6.90 & 9.62 & 2.80 & 407.34 \\
$\begin{array}{l}\text { Paddy locust (Nomadacris } \\
\text { succincta L.) }\end{array}$ & Imago & 65.42 & 10.91 & 15.48 & 3.26 & 421.79 \\
$\begin{array}{l}\text { Cricket (Gryllus sp.) } \\
\text { Silkworm (Bombyx mori L.) }\end{array}$ & Imago/nymph & 32.59 & 29.16 & 30.76 & 4.25 & 515.84 \\
$\begin{array}{l}\text { Giant mealworm (Zophobas } \\
\text { morio F.) }\end{array}$ & Lupae & 60.03 & 29.47 & 0.92 & 5.79 & 509.03 \\
$\begin{array}{l}\text { Yellow mealworm (Tenebrio } \\
\text { molitor L.) }\end{array}$ & Larvae & 49.96 & 28.98 & 14.21 & 3.41 & 517.50 \\
\hline
\end{tabular}

varies greatly among the species. In fact, the same species but from different regions have different nutritional values as shown in Table 2. According to Kouřimská and Adámková (2016) and Adámková et al. (2017), the nutritional value of insects is influenced by many factors such as diet, climatic condition and stage of insect (egg; larvae; nymph/pupae; adult/imago).

\section{A. Protein}

The protein content of the insect samples ranged from 32.59 to $76.69 \%$. Grasshoppers was found to have the highest percentage

Table 2. Nutritional composition of some insects from different region

\begin{tabular}{|c|c|c|c|c|c|c|}
\hline Species & Species & $\begin{array}{c}\text { Protein } \\
(\%)\end{array}$ & $\begin{array}{c}\text { Lipid } \\
(\%)\end{array}$ & $\begin{array}{c}\text { Carbohydrate } \\
(\%)\end{array}$ & $\begin{array}{l}\text { Ash } \\
(\%)\end{array}$ & References \\
\hline Valanga nigricornis & - & - & - & - & - & No data available \\
\hline \multirow[t]{2}{*}{ Nomadacris succincta } & Indonesia & 24.40 & 1.50 & - & - & Lukiwati (2010) \\
\hline & Thailand & 27.60 & 4.70 & - & - & Yhoung-aree (2010) \\
\hline \multirow{3}{*}{ Gryllus sp. } & Indonesia & 56.00 & 32.00 & - & - & Adámková et al. (2017) \\
\hline & South Korea & 58.32 & 11.88 & - & 9.69 & Ghosh et al. (2017) \\
\hline & Unknown & 20.10 & 15.06 & - & - & Payne et al. (2016) \\
\hline \multirow{6}{*}{ Bombyx mori } & South Korea & 52.58 & 19.21 & 23.41 & 4.80 & Kim et al. (2017) \\
\hline & Thailand & 9.60 & 5.60 & 2.30 & - & $\begin{array}{l}\text { Sirimungkararat et al. } \\
\text { (2010) }\end{array}$ \\
\hline & Thailand & 14.70 & 8.30 & - & - & Yhoung-aree (2010) \\
\hline & India & 48.70 & 30.10 & - & 8.60 & $\begin{array}{l}\text { Rumpold \& Schlüter, } \\
\text { (2013) }\end{array}$ \\
\hline & Mexico & 58.00 & 35.00 & - & 4.00 & $\begin{array}{l}\text { Rumpold \& Schlüter, } \\
\text { (2013) }\end{array}$ \\
\hline & Unknown & 14.80 & 8.26 & - & - & Payne et al. (2016) \\
\hline \multirow[b]{3}{*}{ Zophobas morio } & Indonesia & 46.00 & 35.00 & - & - & Adámková et al. (2017) \\
\hline & USA & 43.13 & 40.80 & - & 3.50 & $\begin{array}{l}\text { Rumpold \& Schlüter, } \\
\text { (2013) }\end{array}$ \\
\hline & USA & 46.79 & 42.04 & - & 2.38 & $\begin{array}{l}\text { Rumpold \& Schlüter, } \\
\text { (2013) }\end{array}$ \\
\hline
\end{tabular}




\begin{tabular}{|c|c|c|c|c|c|c|}
\hline Species & Species & $\begin{array}{c}\text { Protein } \\
(\%)\end{array}$ & $\begin{array}{c}\text { Lipid } \\
(\%)\end{array}$ & $\begin{array}{c}\text { Carbohydrate } \\
(\%)\end{array}$ & $\begin{array}{l}\text { Ash } \\
(\%)\end{array}$ & References \\
\hline \multirow{11}{*}{ Tenebrio molitor } & Indonesia & 52.00 & 31.00 & - & - & Adámková et al. (2017) \\
\hline & Indonesia & 48.00 & 40.00 & - & 3.00 & $\begin{array}{l}\text { Yulianingsih \& Al } \\
\text { Awwaly (2015) }\end{array}$ \\
\hline & South Korea & 53.22 & 15.36 & - & 3.88 & Ghosh et al. (2017) \\
\hline & South Korea & 49.80 & 37.11 & 9.60 & 3.50 & Kim et al. (2017) \\
\hline & USA & 47.18 & 43.08 & - & 3.08 & $\begin{array}{l}\text { Rumpold \& Schlüter, } \\
\text { (2013) }\end{array}$ \\
\hline & USA & 49.43 & 38.07 & - & 2.84 & $\begin{array}{l}\text { Rumpold \& Schlüter, } \\
\text { (2013) }\end{array}$ \\
\hline & USA & 49.08 & 35.17 & - & 2.36 & $\begin{array}{l}\text { Rumpold \& Schlüter, } \\
\text { (2013) }\end{array}$ \\
\hline & Mexico & 47.70 & 37.70 & - & 3.00 & $\begin{array}{l}\text { Rumpold \& Schlüter, } \\
\text { (2013) }\end{array}$ \\
\hline & Belgium & - & 31.97 & - & & Paul et al. (2017) \\
\hline & Belgium & - & 6.90 & - & - & Poma et al. (2017) \\
\hline & Unknown & 19.40 & 12.30 & - & - & Payne et al. (2016) \\
\hline
\end{tabular}

of crude protein for every $100 \mathrm{~g}$ dry weight, while cricket had the lowest. The difference of protein content between the lowest and the highest values is quite big which is about twice of the lowest.

Insects are highly effective organisms in converting food into body proteins (Feng et al., 2018). Protein is the main content of insects and its percentage varies depending on the species, level of individual development, sex, feed type, climate, and geographical location. Among six species of insects analyzed, crickets have the lowest protein content, which is about $32.59 \%$. Nevertheless, the percentage is much higher than the lowest value of insect protein content recorded by researchers such as Banjo, Lawal and Songonuga (2006), Chen, Feng and Chen (2009), Rumpold and Schlüter (2013). This suggests that all six specimens tested are considered viable to be used as an alternative protein source, since the highest protein content of vegetable sources is only $35.8 \%$, ie soybean (Rumpold \& Schlüter, 2013).

\section{B. Fat}

Similar to protein, total fat content was also found to vary between $6.90-29.47 \%$. Silkworm pupae contained the highest body fat in each
$100 \mathrm{~g}$ dry weight, while the smallest was of the javanese grasshopper. The difference of grasshoppers' body fat with other insects is considerably high. Grasshoppers have much lower fat content, which is only a quarter or one third of other insects.

Fat is a large nutritional component found in insects after protein. Fat is important not only because it could act as an energy producer, but also as a provider of essential fatty acids and some types of fat-soluble vitamins (Paul et al., 2017). According to Rumpold and Schlüter (2013), the fatty acids content in most insects are predominantly unsaturated fatty acids. Binkoski, Kris-Etherton, Wilson, Mountain and Nicolosi (2005) mentioned that fatty acids of the PUFA (poly-unseturated fatty acids) group are important and indispensable for lowering cholesterol levels in the body. In this study, no measurements and calculations of the content of each type of fatty acids were recorded, so the value of saturated fat (SFA, saturated fatty acid) and unsaturated fat (UFA, unsaturated fatty acid) remain unknown, either in the form of PUFA or MUFA (mono-unsaturated fatty acid) in each insect sample. However, according to DeFoliart (1991), the type of fatty acid in 
insects has a level of unsaturation comparable to poultry and fish but contains a higher type of PUFA. Siriamornpun and Thammapat (2008) reported that the fatty acids of edible insects in Thailand are mostly in the form of PUFA, but others are dominated by MUFA type. The authors said that the total concentrations of PUFA are comparable to those found in meat and some fish, and much higher than in fresh vegetables. Thus it can be said that in terms of fat content, insect is a healthy foods. However, although there is no evidence of any accumulation of fatty acids that are toxic, for food safety it is necessary to identify certain unknown constituents of fatty acids in insects (Paul et al., 2017).

\section{Carbohydrate}

Carbohydrate content varies between species of insects, ranging from 0.92 to $30.76 \%$ per $100 \mathrm{~g}$ dry weight. The lowest percentage was identified in the silkworm pupa, while the highest was found in crickets.

Insects generally contain low carbohydrates. Siriamornpun and Thammapat (2008) explained that the carbohydrate content of several species of insects in Thailand ranges from $7-16 \%$, comparable to some insects in Nigeria which contain about $7-20 \%$. In this study, it is below $20 \%$ on average except for cricket and yellow mealworm. According to Chen et al. (2009) as cited from Sun (2007) insects contain polysaccharides that is sufficient to increase the immune system in the human body. In addition, because it is classified as low-carbohydrate-high protein (LC-HP), insect diets are highly beneficial for reducing the risk of cardiovascular disease and for the purpose of weight loss (Siriamornpun \& Thammapat, 2008).

\section{Ash}

Although ash content shows variation between insect species, the differences among the species are not too much. The percentage of ash content per $100 \mathrm{~g}$ of dry weight ranges between 2.8\% (the lowest) and 5.79\% (the highest). The lowest percentage was found in the javanese grasshopper, while the highest was in silkworms.

\section{E. Energy}

The value of energy shows that the number varies with the highest value reaching $517.5 \mathrm{kcal}$ found in giant mealworm, and the lowest was found in paddy locust about $407.34 \mathrm{kcal}$. Energy is a result of protein, fat, and carbohydrate metabolism and its value mainly depends on the fat content. Sufficient energy in meals is important to fully utilize protein in the diet to energize the growth, temperature control and physical activities (Hardinsyah et al., 2013) The high value of caloric content of insects shows that they could be used as complement to the diet in order to increase the intake of high quality protein and to guarantee the use of protein completely.

\section{F. Mineral}

The body of insects contain micronutrient, both minerals and vitamins, each of which has an important role in various biological processes within the organism, including the human body. Various types of minerals are found in insects such as iron, zinc, copper, calcium, potassium, magnesium and others (van Huis et al., 2013). The study found that mineral content of iron $(\mathrm{Fe})$ and calcium $(\mathrm{Ca})$ varies between species of insects. Table 3 shows the weight of two types of minerals per $100 \mathrm{~g}$ dry weight. Ca content ranges from 24.82 to $31.22 \mathrm{mg}$, while the Fe content ranges from 3.15 to $4.10 \mathrm{mg}$. The highest content of $\mathrm{Ca}$ is found in javanese grasshopper and the lowest is found in the giant mealworm, while the highest Fe content is found in the yellow mealworm and the lowest is found in paddy locusts. Both are essential minerals for human to help the body perform regulatory and structural functions. Iron is not only important for energy metabolism, it is also needed in the immune system, cognitive development, and in physical performance (Abbaspour, Hurrell, \& Kelishadi, 2014). While calcium is essential for the maintenance of bone 
Table 3. Fe and Ca contents of some edible insects per $100 \mathrm{~g}$ dry weight

\begin{tabular}{llcc}
\hline \multicolumn{1}{c}{ Specimen } & \multicolumn{1}{c}{ Stadia } & Ca (mg) & Fe (mg) \\
\hline Javanese grasshopper (Valanga nigricornis) & Imago & 31.22 & 3.20 \\
Paddy locust (Nomadacris succincta) & Imago & 27.10 & 3.15 \\
Cricket (Gryllus sp.) & Imago/nymph & 25.49 & 3.25 \\
Silkworm (Bombyx mori) & Pupa & 29.17 & 3.54 \\
Giant mealworm (Zophobas morio) & Larva & 24.82 & 3.19 \\
Yellow mealworm (Tenebrio molitor) & Larva & 27.61 & 4.10 \\
\hline
\end{tabular}

health during growing phases, the preservation of bone mineral density in elderly individuals (Shin \& Kim, 2015) and the function of nerves and muscles to perform normally (Soetan, Olaiya, \& Oyewole, 2010).

Iron $(\mathrm{Fe})$ is a mineral that serves an important role in the formation of red blood cells. Fe deficiency causes anemia, a disease declared by the World Health Organization (WHO) to be the most common among people in many parts of the world, especially in developing countries (van Huis et al., 2013). Iron is classified as micro (trace)-element, a category for an inorganic substance that is required in a small amount (less than $100 \mathrm{mg} / \mathrm{dl}$ ) in the body to maintain certain physicochemical processe for normal life (Soetan et al., 2010). According to Abbaspour et al. (2014), the average adult stores about 1-3 $\mathrm{g}$ of iron in his or her body and needs daily intake to replace the loss of it through stools, urine, and sloughing skin and mucosal surfaces. The loss of iron is approximately 0.9 $\mathrm{mg}$ in adult male and $0.8 \mathrm{mg}$ in adult female.

Iron is one of many minerals contained in insects. Some species, such as Locusta migratoria and Gonimbrasia belina, even contain $\mathrm{Fe}$ much higher than beef (Bauserman et al., 2015; Oonincx et al., 2010). Iron content of insects also has higher solubility rate than that derived from beef (Latunde-Dada, Yang, \& Vera Aviles, 2016). Iron and calcium contents are lower than the average value of both minerals in insects and beef analyzed by Latunde-Dada et al. (2016). According to Oonincx and van der Poel (2011), the mineral content of insects depends on the type of food. Nonetheless, data in Table 3 shows the iron content of all samples are much higher than the average loss of $\mathrm{Fe}$ in the daily life of both adult male and female. It means that the amount of iron in each species of insects is readily available to replace the loss of Fe to maintain the balance of its storage in human body.

In general the insects have nutritional values that is adequate to be used as food in term of their contents of protein, fat, carbohydrate and energy potential. The result is similar with those of Feng et al. (2018), who has documented the nutritional value of 174 insect species in China many of them belonging to edible insects category. Some species in our study even have much higher value than other food materials that are commonly consumed in the society. Table 4 shows the nutritional content of meat, fish, eggs, tempeh (fermented soybean cake) and tofu, the food which is commonly consumed by the community. Therefore, insects deserve to be taken into account to combating problem of malnutrition, especially in areas of deprivation and low purchasing power, and to ensure food security (Belluco et al., 2015; Gahukar, 2011; Ghosh et al., 2017; van Huis et al., 2013). Insects are not only able to provide adequate protein and energy and meet the needs of the amino acids that humans require, but also provide unsaturated fatty acids in the form of mono- and poly-unsaturated fatty acids that are good for the body and rich 
Table 4. Nutritional composition of some commonly consumed foods

\begin{tabular}{lrrrl}
\hline \multicolumn{1}{c}{ Food Materials } & Protein $(\%)$ & Lipid $(\%)$ & Ash $(\%)$ & \multicolumn{1}{c}{ References } \\
\hline Beef & 55 & 41 & - & van Huis et al. (2013) \\
& 20 & 7.2 & - & Sirimungkararat et al. (2010) \\
& 21.07 & 0.87 & 1.37 & Prasetyo et al. (2009) \\
Sheep & $22.83-23.31$ & $4.17-4.23$ & $1.14-1.31$ & Muliana et al. (2016) \\
& 14.6 & 30.5 & - & Lukiwati (2010) \\
Pig & 28.22 & - & - & Anna (2014) \\
& 13 & 33.3 & - & Lukiwati (2010) \\
Poultry & 14.1 & 35 & - & Sirimungkararat et al. (2010) \\
& 20.5 & 4.3 & - & Lukiwati (2010) \\
& 20.8 & 2.4 & - & Sirimungkararat et al. (2010) \\
Boiled egg & 18.71 & 13.74 & - & Sundari et al. (2015) \\
& 12.58 & - & - & Anna (2014) \\
Mackerel fish & $13.79-14.76$ & - & - & Mawaddah (2010) \\
Tilapia/ cichlid & 18.44 & 11.14 & - & Sundari et al. (2015) \\
fish & $12.94-16.79$ & $0.10-0.18$ & & Ramlah et al. (2016) \\
Tempeh & 13.84 & 6.78 & - & Sundari et al. (2015) \\
Tofu & 10.1 & 6.06 & - & Sundari et al. (2015) \\
\hline
\end{tabular}

in vitamins and minerals (Rumpold \& Schlüter, 2013). Insects also contain iron in sufficient quantities to overcome the problem of anemia due to deficiency of mineral Fe (Latunde-Dada et al., 2016).

Result shows that insects are very worthy to be utilized as much as possible to fulfill human needs of food, especially as an alternative source of animal protein. Though the nutritional composition of insects varyies widely, but in general it provides satisfactory nutrients for human (van Huis, 2015). Currently, the attention of the world community to entomophagy has grown, partly triggered by FAO publication in 2013 of "Edible insects: Future prospects for food and feed security" (Hartmann \& Siegrist, 2017; van Huis, 2015), although the use of insects as food has been practiced in various countries, predominately in developing countries. It is time for Indonesia as a tropical country with a high diversity of insects to put more attention to the use of insects as food.
No doubt in reality most people still feel disgusted and reluctant to eat insects, although the culture of eating insects actually has long been living in some communities in various regions in Indonesia. Awareness campaign and socialization need to be done to the community, especially to those who lives in the forest surrounding, to utilize thoroughly the richness of insects in their sphere. Further research and studies are required to make insects more attractive to wider communities to consume.

\section{CONCLUSION}

Each species of insect has variety of nutritional content. Each $100 \mathrm{~g}$ of dry weight contains $32.59-76.69 \%$ protein, $6.9-29.47 \%$ fat, $0.92-30.76 \%$ carbohydrate, $2.80-5.79 \%$ ash, 407.34- $517.5 \mathrm{kcal}$ energy, and minerals $\mathrm{Ca}$ and Fe about 24.82-31.22 $\mathrm{mg}$ and 3.15-4.1 $\mathrm{mg}$.

As the main ingredient of insect nutrients, protein content of some types of insects is relatively high. Hence, it is a potential alternative 
to animal protein source other than meat and fish to increase protein intake. In addition, it is not only insects that come from the nature, some of the insects that have been cultivated have also the potential to be utilized as food, including silkworm pupae and crickets.

Insects could also be taken into account as food to fight against malnutrition problem and to increase nutrient intake given the nutrition contained in it is quite adequate. Efforts should be made to encourage the consumption of edible insects as an alternative source of protein. It is especially important to those who lives in the forest surrounding, since the forest area is an excellent habitat for various species of insects.

Considering that not all species of insects are edible, even some of them could be harmful to human health, data collection and more indepth research are continuously needed to produce a list of insects which are edible and worthy.

\section{ACKNOWLEDGEMENT}

The study was funded by the Forest Research and Development Center (FRDC), The Research, Development, and Innovation Agency for Environment and Forestry, under the annual budget for year 2016. We would like to thank to the Director of FRDC and all staff members who have facilitated the funding and have assisted the implementation of the research.

\section{REFERENCES}

Abbaspour, N., Hurrell, R., \& Kelishadi, R. (2014). Review on iron and its importance for human health. Journal of Research in Medical Sciences, 19, 164-174.

Adámková, A., Mlček, J., Kouřimská, L., Borkovcová, M., Bušina, T., Adámek, M., Bednářová, M., \& Krajsa, J. (2017). Nutritional potential of selected insect species reared on the island of Sumatra. International Journal of Environmental Research and Public Health, 14(5), 1-10. doi:10.3390/ijerph14050521.
Alamu, O.T., Amao, A.O., Nwokedi, C.I., Oke, O.A., \& Lawa, I.O. (2013). Diversity and nutritional status of edible insects in Nigeria: A review. International Journal of Biodiversity and Conservation, 5(4), 215-222. doi:10.5897/ IJBC12.121.

Anna, L. K. (2014). Daging atau telur yang memiliki lebih banyak protein?. Retrieved May 30, 2017 from http://nationalgeographic.co.id/ berita/2014/04/daging-atau-telur-yangmemiliki-lebih-banyak-protein.

AOAC. (2005). Official methods of analysis of $A O A C$ International. (D. W. Horwitz, Ed.) (18 ${ }^{\text {th }}$ ed.). Maryland: AOAC International.

Asthami, N., Estiasih, T., \& Maligan, J. M. (2016). Mie instan belalang kayu (Melanoplus cinereus): Kajian pustaka. Jurnal Pangan dan Agroindustri, 4(1), 238-244.

Banjo, A.D., Lawal, O.A., \& Songonuga, E. A. (2006). The nutritional value of fourteen species of edible insects in South Western Nigeria. African Journal of Biotechnology, 5(1684-5315), 298-301. doi:10.5897/AJB05.250.

Bauserman, M., Lokangaka, A., Gado, J., Close, K., Wallace, D., Kodondi, K.K., Tshefu, A., \& Bose, C. (2015). A cluster-randomized trial determining the efficacy of caterpillar cereal as a locally available and sustainable complementary food to prevent stunting and anaemia. Public Health Nutrition, 18(10), 178592. doi:10.1017/S1368980014003334.

Belluco, S., Losasso, C., Maggioletti, M., Alonzi, C., Ricci, A., \& Paoletti, M. G. (2015). Edible insects: A food security solution or a food safety concern? Animal Frontiers, 5(2), 25-30. doi:10.2527/af.2015-0016.

Binskonski, A.E., Kris-Etherton, P.M., Wilson, T.A., Mountain, M.L., \& Nicolosi, R. J. (2005). Balance of unsaturated fatty acids is important to a cholesterol-lowering diet: Comparison of mid-oleic sunflower oil and olive oil on cardiovascular disease risk factors. Journal of the American Dietetic Association, 105(7), 1080 1086. doi:10.1016/j.jada.2005.04.009.

Bodenheimer, F. S. (1951). Insects as human food. Springer-Science+Business Media, B.V. doi:10.1007/978-94-017-6159-8.

Chen, X., Feng, Y., \& Chen,Z. (2009). Commonedible insects and their utilization in China: Invited review. Entomological Research, 39(5),299-303. doi:10.1111/j.1748-5967.2009.00237.x. 
DeFoliart, G. R. (1991). Insect fatty acids: Similar to those of poultry and fish in their degree of unsaturation, but higher in the polyunsaturates. The Food Insect Newsletter, 4(1), 1-8.

Durst, P.B. \& Shono, K. (2010). Edible forest insects: Exploring new horizons and traditional practices. In P. B. Durst, V. D. Johnson, R. N. Leslie, \& K. Shono (Eds.), Forest insects as food: Human bite back (pp. 1-4). Bangkok, Thailand: Food and Agriculture of the United Nations, Regional Office for Asia and the Pacific.

Feng, Y., Chen, X.M., Zhao, M., He, Z., Sun, L., Wang, C.Y., \& Ding, W. F. (2018). Edible insects in China: Utilization and prospects. Insect Science, 25(2), 184-198. doi:10.1111/17447917.12449.

Gahukar, R. T. (2011). Entomophagy and human food security. International Journal of Tropical Insect Science, 31(3), 129-144. doi:10.1017/ S1742758411000257.

Ghosh, S., Lee, S.-M., Jung, C., \& Meyer-Rochow, V. B. (2017). Nutritional composition of five commercial edible insects in South Korea. Journal of Asia-Pacific Entomology, 20, 686-694. doi:10.1016/j.aspen.2017.04.003.

Halloran, A., Vantomme, P., Hanboonsong, Y., \& Ekesi, S. (2015). Regulating edible insects: the challenge of addressing food security, nature conservation, and the erosion of traditional food culture. Food Security, 7(3), 739-746. doi:10.1007/s12571-015-0463-8.

Hardinsyah, Riyadi, H., \& Napitupulu, V. (2013). Kecukupan energi, protein, lemak, dan karbohidrat. Retrieved February 18, 2016 from https://www.researchgate.net/ publication/301749209_KECUKUPAN_ ENERGI_PROTEIN_LEMAK_DAN_ KARBOHIDRAT.

Hariyadi, P. (2015). Peranan pangan hewani dalam pembangunan SDM bangsa. Umami Indonesia, 12-14.

Hartmann, C., \& Siegrist, M. (2017). Insects as food: Perception and acceptance. Findings from current research. Ernahrungs Umschau, 64(3), 44-50. doi:10.4455/eu.2017.010.

Kim, S., Weaver, C. M., \& Choi, M. (2017). Proximate composition and mineral content of five edible insects consumed in Korea. CyTA - Journal of Food, 15(1), 143-146. doi:10 $.1080 / 19476337.2016 .1223172$.
Kouřimská, L., \& Adámková, A. (2016). Nutritional and sensory quality of edible insects. NFS Journal, 4, 22-26. doi:10.1016/j. nfs.2016.07.001.

Latunde-Dada, G. O., Yang, W., \& Vera Aviles, M. (2016). In vitro iron availability from insects and sirloin beef. Journal of Agricultural and Food Chemistry, 64(44), 8420-8424. doi:10.1021/ acs.jafc.6b03286.

Lukiwati, D. R. (2010). Teak caterpillars and other edible insects in Java. In P. B. Durst, V. D. Johnson, R. N. Leslie, \& K. Shono (Eds.), Forest insects as food: Human bite back (pp. 99-103). Bangkok, Thailand: Food and Agriculture of the United Nations, Regional Office for Asia and the Pacific.

Makore, T. A., Garamumhango, P., Chirikure, T., \& Chikambi, S. D. (2015). Determination of nutritional composition of Encosternum delegorguei caught in Nerumedzo community of Bikita, Zimbabwe. International Journal of Biology, 7(4), 13. doi:10.5539/ijb.v7n4p13.

Mawaddah, N. (2010). Pengaruh cara pengolahan terhadap kadar protein dan kolesterol pada berbagai jenis telur. (Thesis). Sunan Kalijaga State Islamic University, Yogyakarta.

Mlcek, J., Rop, O., Borkovcova, M., \& Bednarova, M. (2014). A comprehensive look at the possibilities of edible insects as food in Europe - A review. Polish Journal of Food and Nutrition Sciences, 64(3), 147-157. doi:10.2478/ v10222-012-0099-8.

Muliana, I.K., Ariana, I.N.T., \& Oka, A. A. (2016). Komponen kimia daging di lokasi otot yang berbeda pada sapi Bali yang digembalakan di Area tempat pembuangan sampah. Peternakan Tropika, 4(3), 590-602.

Oonincx, D.G.A.B., \& van der Poel, A. F. B. (2011). Effects of diet on the chemical composition of migratory locusts (Locusta migratoria). Zoo Biology, 30(1), 9-16. doi:10.1002/zoo.20308.

Oonincx, D.G.A.B., van Itterbeeck, J., Heetkamp, M.J.W., van den Brand, H., van Loon, J.J.A., \& van Huis, A. (2010). An exploration on greenhouse gas and ammonia production by insect species suitable for animal or human consumption. PLoS One, 5(12). doi:10.1371/ journal.pone.0014445.

Pal, P. \& Roy, S. (2014). Edible insects: Future of human food - A review. International Letters of 
Natural Sciences, 26, 1-11. doi:10.18052/www. scipress.com/ILNS.26.1.

Paul, A., Frederich, M., Megido, R.C., Alabi, T., Malik, P., Uyttenbroeck, R., Francis, R., Blecker, C., Haubruge, E., Lognay, G., \& Danthine, S. (2017). Insect fatty acids: A comparison of lipids from three Orthopterans and Tenebrio molitor L. larvae. Journal of Asia-Pacific Entomology, 20(2), 337-340. doi:10.1016/j. aspen.2017.02.001.

Payne, C.L.R., Scarborough, P., Rayner, R., \& Nonaka, K. (2016). Are edible insects more or less 'healthy' than commonly consumed meats? A comparison using two nutrient profiling models developed to combat overand undernutrition. European Journal of Clinical Nutrition, 70(May), 285-291. doi:10.1038/ ejcn.2015.149.

Poma, G., Cuykx, M., Amato, E., Calaprice, C., Focant, J.F., \& Covaci, A. (2017). Evaluation of hazardous chemicals in edible insects and insect-based food intended for human consumption. Food and Chemical Toxicology, 100, 70-79. doi:10.1016/j.fct.2016.12.006.

Prasetyo, A., Prasetyo, T., \& Subandriyo. (2009). Tinjauan gizi, finansial dan mikrostruktur otot dari sapi glonggongan (pp. 322-332). Paper presented in the Seminar Nasional Teknologi Peternakan dan Veteriner 2009. Retrieved June 1, 2017 from http://peternakan.litbang. pertanian.go.id/fullteks/semnas/pro09-46. pdf? secure $=1$.

Ramandey, E. \& van Mastrigt, H. (2010). Edible insects in Papua, Indonesia: from delicious snack to basic need. In P. B. Durst, V. D. Johnson, R. N. Leslie, \& K. Shono (Eds.), Forest insects as food: Human bite back (pp. 105-113). Bangkok, Thailand: Food and Agriculture of the United Nations, Regional Office for Asia and the Pacific.

Ramlah, Soekendarsi, E., Hasyim, Z., \& Hasan, M. S. (2016). Perbandingan kandungan gizi ikan nila Oreocbromis niloticus asal Danau Mawang Kabupaten Gowa dan danau Universitas Hasanuddin kota Makassar. Jurnal Biologi Makassar (Bioma), 1(1), 39-46.

Ramos-Elorduy, J., Moreno, JMP., Prado, EE., Perez, MA., Otero, JL., \& De Guevara, O. (1997). Nutritional value of edible insects from the State of Oaxaca, Mexico. Journal of Food Composition and Analysis, 10, 142-157. doi:10.1006/jfca.1997.0530.

Rumpold, B.A. \& Schlüter, O. K. (2013). Nutritional composition and safety aspects of edible insects. Molecular Nutrition and Food Research, 57(5), 802-823. doi:10.1002/mnfr.201200735.

Shin, C. S., \& Kim, K. M. (2015). The risks and benefits of calcium supplementation. Endocrinology and Metabolism, 30(1), 27-34. doi:10.3803/EnM.2015.30.1.27.

Siriamornpun, S., \& Thammapat, P. (2008). Insects as delicacy and a nutritious food in Thailand. In G. L. Robertson \& J. R. Lupien (Eds.), Using food science and technology to improve nutrition and promote national development. Canada: International Union of Food Science \& Technology.

Sirimungkararat, S., Saksirirat, W., Nopparat, T., \& Natongkham, A. (2010). Edible products from eri silkworm (Samia racini D.) and mulberry silkworm (Bombyx mori L.) in Thailand. In P. B. Durst, V. D. Johnson, R. N. Leslie, \& K. Shono (Eds.), Forest insects as food: Human bite back (pp. 189-200). Bangkok, Thailand: Food and Agriculture of the United Nations, Regional Office for Asia and the Pacific.

Soetan, K. O., Olaiya, C. O., \& Oyewole, O. E. (2010). The importance of mineral elements for humans, domestic animals and plants. African Journal of Food Science, 4(5), 200-222. doi:10.1186/s12302-017-0116-y.

Sun, L., Feng, Y., He, Z., Ma, T., \& Zang, X. (2007). Studies on alkaline solution extraction of polysaccharide from silkworm pupa and its immunomodulating activities (in Chinese). Forest Research, 20(6), 782-786.

Sundari, D., Almasyhuri \& Lamid, A. (2015). Pengaruh proses pemasakan terhadap komposisi zat gizi bahan pangan sumber protein. Media Litbangkes, 25(4), 235-242.

Tiroesele, B., Seletlo, B.R., \& Moreki, J. C. (2013). Proximate and mineral analyses of the hawk moth larvae (Agrius convolvuli L.) harvested in Mogonono, Kweneng District, Botswana. International Journal of Innovative Research in Science, Engineering and Technology, 2(9), 49264931.

van Huis, A. (2015). Edible insects contributing to food security? Agriculture \& Food Security, 4(20) 1-9. doi:10.1186/s40066-015-0041-5. 
van Huis, A., Itterbeeck, J.V., Klunder, H., Mertens, E., Halloran, A., Muir, G., \& Vantomme, P. (2013). Edible insects. Future prospects for food and feed security. Food and Agriculture Organization of the United Nations, 171. doi:10.1017/CBO9781107415324.004.

Yhoung-aree, J. (2010). Edible insects in Thailand: nutritional values and health concerns. In P. B. Durst, V. D. Johnson, R. N. Leslie, \& K. Shono (Eds.), Forest insects as food: Human bite back (pp. 201-216). Bangkok, Thailand: Food and Agriculture of the United Nations, Regional Office for Asia and the Pacific.
Yulianingsih, R. \& Al Awwaly, K. U. (2015). Alih teknologi budidaya ulat pada kelompok peternak ulat Hongkong di Desa Oro-Oro Ombo, Kota Batu. Journal of Innovation and Applied Technology, 1(88), 111-117. 